\title{
Analysis of the Geographically and Temporally Weighted Regression (GTWR) of the GRDP the Construction Sector in Java Island
}

\author{
Sugi Haryanto ${ }^{1,}{ }^{*}$, Muhammad Nur Aidi ${ }^{2}$, Anik Djuraidah ${ }^{2}$ \\ ${ }^{1}$ Sub directorate of Construction Statistics at BPS-Statistics Indonesia, Jl. dr. Sutomo No. 6-8, Jakarta \\ 10710 \\ Master of Applied Statistics IPB University \\ ${ }^{2}$ Lecturer at Statistics Department, IPB University, Jl. Meranti Wing 22 Level 4, IPB Dramaga, \\ Bogor 16680, Indonesia \\ *) Corresponding Author (e-mail: sugih@bps.go.id)
}

Received: 14 December 2018 / Accepted: 13 August 2019 / Published: 16 August 2019

\begin{abstract}
The construction sector is one of the sectors that has strategic value in the national economy of Indonesia. Economic activity in an area is measured using Gross Regional Domestic Product (GRDP), therefore the development of economic activities in the construction sector can be seen from its GRDP. The Geographically and Temporally Weighted Regression (GTWR) model is a development of the Geographically Weighted Regression (GWR) model which takes into account the diversity of locations and times. This study used secondary data, namely the GRDP of the construction sector as a response variable, and four explanatory variables, namely the size of population, local revenue, area and the number of construction establishments. The purpose of the study is to determine the factors that influence each regency/municipality each year observing the GRDP of the construction sector in Java together with the GTWR model. This model is more effective in describing the GRDP value of the construction sector of regencies/municipalities in Java Island in 2010-2016. This is indicated by the decrease in the values of Root Mean Square Error (RMSE), Mean Absolute Deviation (MAD), and the Mean Absolute Percentage Error (MAPE).
\end{abstract}

Keywords: construction, GRDP, GRDP the construction sector, GTWR, spatial

Abstrak. Sektor konstruksi adalah salah satu sektor yang memiliki nilai strategis dalam perekonomian nasional. Aktivitas ekonomi di suatu daerah diukur menggunakan Produk Domestik Regional Bruto (PDRB). Perkembangan kegiatan ekonomi di sektor konstruksi dapat dilihat dari PDRB sektor konstruksi. Model Geographically and Temporally Weighted Regression (GTWR) adalah pengembangan dari model Geographically Weighted Regression (GWR) dengan mempertimbangkan keragaman lokasi dan waktu. Penelitian ini menggunakan data sekunder, yaitu data PDRB sektor konstruksi sebagai variabel respon dan empat variabel penjelas, yaitu jumlah penduduk, pendapatan daerah, luas, dan jumlah perusahaan konstruksi. Tujuan dari penelitian ini adalah untuk menentukan faktor-faktor yang mempengaruhi masing-masing kabupaten / kota dan setiap tahun mengamati PDRB sektor konstruksi di Jawa dengan model GTWR. Model GTWR lebih efektif untuk menggambarkan nilai PDRB sektor konstruksi kabupaten/kota di Pulau Jawa pada 2010-2016. Ini ditunjukkan oleh penurunan nilai Root Mean Square Error (RMSE), Mean Absolute Deviation (MAD), dan Mean Absolute Perscentage Error (MAPE).

Kata kunci: konstruksi, PDRB, PDRB sector konstruksi, GTWR, spasial 


\section{Introduction}

Construction is an economic activity that produces goods and services related to buildings, which are integrated with the land where they are located, and used as places of residence or for other fields of activity. The construction sector has strategic value in the national economy (BPS-Statistics Indonesia, 2017). It plays an important role in national economic conditions, determined by the size of the its contribution to the growth of other business sectors. The development of the construction sector will support the creation of social and economic infrastructure, creating better accessibility, which can spur the growth of other economic sectors (Giyarsih, 2010). Infrastructure development is the focus of the government development set out in the 20152019 National Medium-Term Development Plan (NMTDP). It consists of various types of development projects, including the construction of roads, bridges, airports, amongst others. Based on the ministry/agency agreement only 30 projects were prioritized, most of which were located in Java. The development of the property sector, which is supported by the growth of the construction sector, can expand central economics (Wibowo et al., 2018).

The development of the construction sector needs to be monitored and evaluated with actual, accurate and continuous statistical data (BPS-Statistics Indonesia, 2016). The regional economy is said to grow and develop if the goods and services produced in a certain period are greater than in the previous period, which is then reduced to value-added. Gross Regional Domestic Product (GRDP) is one of the indicators used to measure economic activity in a region. Therefore, the development of economic activities in the construction sector can be seen from its GRDP.

Several studies on factors that influence GRDP have been conducted. Safitri and Aliasuddin (2016) found that the population had a positive and significant effect. Nasution (2010) examined the effect of PAD on the PDRB of Banten Province, with significant influential results. Putra's (2015) research established that the area had a significant influence, but in a negative direction, while Afandi and Soesatyo's (2014) research shows that the number of industrial manufacturers has a positive influence on GRDP.

Data based on the regional and time require analysis that considers the diversity between regions and times. Such diversity occurs due to differences in characteristics, which are influenced by culture, economy, education, thought and recreation, amongst others (Jayadinata, 1999). The development of a region involves the process of changing characteristics over time (Anisah et al., 2017). The analytical method used in the study is Geographically and Temporally Weighted Regression (GTWR), developed by Huang et al. (2010) to model housing prices in the city of Calgary (Canada) in 2002-2004. The GTWR model is a development of the Geographically Weighted Regression (GWR) method developed by Brunsdon et al. (1996), Fotheringham et al. (1996) and Fotheringham et al. (2003), which considers the elements of location and time. The results of GTWR model were regression models whose parameter values apply only to each location and each time of observation (Fotheringham et al., 2015). In GTWR, a weighting matrix element $\mathrm{W}$ is used, whose magnitude depends on the proximity between locations and times. The effect of weighting will be greater the closer a location or time. The weighting function used for GTWR in this paper is the Kernel Bisquare function.

The study uses GRDP data on the construction sector from 119 regencies/ municipalities in Java from the period 2010] to 2016 as the response variable. The factors that will be examined for their influence on the GRDP of the construction sector are population size, local revenue (PAD), area, and the number of construction establishments. The research data has location and time dimensions, so it is possible to use the GTWR model. The benefit of this research is to provide information to regency/municipality governments in 
Java regarding the modeling of factors that affect the GRDP of the construction sector. Consequently, these governments can develop their respective policies more appropriately and evaluate them annually. The purpose of this study is to determine the factors that influence the GRDP of the construction sector in each regency/municipality in Java each year.

\section{Research Method}

\subsection{Data}

The study uses secondary data from Badan Pusat Statistik (BPS-Statistics Indonesia) and the Directorate General of Fiscal Balance (DGFB), namely the GRDP data of the construction sector as a response variable and four explanatory variables, population size, local revenue, area and the number of construction establishments. The scope of the research data is 119 regencies/municipalities in Java Island over the period 2010 to 2016. The variables used in the study are shown in Table 1.

Table 1. Details of the variables used as secondary data

\begin{tabular}{|c|c|c|}
\hline Variable & Unit & Source \\
\hline $\begin{array}{l}\text { GRDP of the } \\
\text { construction } \\
\text { sector }(Y)\end{array}$ & Million rupiah & $\begin{array}{l}\text { BPS-Statistics } \\
\text { Indonesia }\end{array}$ \\
\hline Population $\left(\mathrm{X}_{1}\right)$ & People & $\begin{array}{l}\text { BPS-Statistics } \\
\text { Indonesia }\end{array}$ \\
\hline $\begin{array}{l}\text { Local revenue } \\
\left(\mathrm{X}_{2}\right)\end{array}$ & Million rupiah & DGFB \\
\hline Area $\left(X_{3}\right)$ & $\mathrm{Km}^{2}$ & $\begin{array}{l}\text { BPS-Statistics } \\
\text { Indonesia }\end{array}$ \\
\hline $\begin{array}{l}\text { Number of } \\
\text { Construction } \\
\text { Establishments } \\
\left(\mathrm{X}_{4}\right)\end{array}$ & Establishment & $\begin{array}{l}\text { BPS-Statistics } \\
\text { Indonesia }\end{array}$ \\
\hline
\end{tabular}

\subsection{Geographically and Temporally Weighted Regression (GTWR) Model}

The Geographically and Temporally Weighted Regression (GTWR) method is a development of the GWR method, taking into account location and time elements
(Huang et al. 2010). GTWR takes into account non-stationary spatiotemporal aspects in the parameter estimation, with a weighting matrix based on the distance determined from the coordinates $(x, y, t)$ between observation $i^{\text {th }}$ and all the other observations, according to the GWR technique (Fotheringham et al. 2015). Huang et al. (2010) formulated the GTWR model to be written as follows:

where

$y_{i}=\beta_{0}\left(u_{i}, v_{i}, t_{i}\right)+\sum_{k=1}^{p} \beta_{k}\left(u_{i}, v_{i}, t_{i}\right) x_{i k}+\varepsilon_{i}(1)$

is the value of the response variable observed at location $\left(u_{i^{\prime}} v_{i}\right)$ and time .

The regression coefficient $\beta_{i}\left(u_{i^{\prime}} v_{i^{\prime}} t_{i}\right)$ at point $i$ is obtained by using the Weighted Least Squares (WLS) method, with the following criteria:

$\hat{\beta}\left(u_{i}, v_{i}, t_{i}\right)=\left[\boldsymbol{X}^{T} \boldsymbol{W}\left(u_{i}, v_{i}, t_{i}\right) \boldsymbol{X}\right]^{-1} \boldsymbol{X}^{T} \boldsymbol{W}\left(u_{i}, v_{i}, t_{i}\right)$

where $W\left(u_{i^{\prime}} v_{i^{\prime}}, t_{i}\right)=\operatorname{diag}\left(w_{i 1}, w_{2 n^{\prime}} \ldots, w_{i n}\right)$ is the weighting matrix at location () and time .

If the spatial distance is dS $=\sqrt{\left(u_{i}-u_{j}\right)^{2}+\left(v_{i}-v_{j}\right)^{2}}$ and the temporal distance is $\mathrm{dT},=\sqrt{\left(t_{i}-t_{j}\right)^{2}}$ then these can be combined to form a spatiotemporal distance $d^{S T}$

$$
d^{S T}=\lambda d^{S}+\mu d^{T}
$$

where $\lambda$ and $\mu$ are scale factors to balance the various effects used to measure spatial and temporal distance in the metric system.

If Euclid distance and decay-based distanceGaussian functions are used to construct the spatiotemporal weight matrices, then:

$$
\left(d_{i j}{ }^{S T}\right)^{2}=\lambda\left[\left(u_{i}-u_{j}\right)^{2}+\left(v_{i}-v_{j}\right)^{2}\right]+\mu\left(t_{i}-t_{j}\right)^{2}
$$

For example, $\tau$ is a parameter ratio $\tau=\mu / \lambda$ with $\lambda \neq 0$, so the equation obtained is as follows: 


$$
\frac{\left(d_{i j}{ }^{S T}\right)^{2}}{\lambda}=\left[\left(u_{i}-u_{j}\right)^{2}+\left(v_{i}-v_{j}\right)^{2}\right]+\tau\left(t_{i}-t_{j}\right)^{2}
$$

The parameter $\tau$ is obtained from the criteria by minimizing the cross-validation $(\mathrm{CV})$ by initializing the initial value $\tau$, as below:

$C V(\tau)=\sum_{i=1}^{n}\left[y_{i}-\hat{y}_{\neq i}(\tau)\right]^{2}$

The estimator parameters $\lambda$ and $\mu$ can then be obtained by an iterative method based on the estimation results $\tau$ and which results in a minimum $\mathrm{CV}$.

\subsection{Data Analysis Procedure}

Analysis and modeling were conducted using the statistical program R-3.4.2. The stages of analysis in the study were as follows:

a. Conduct data exploration to obtain an overview and information about the response variable and explanatory variables used.

b. Employ a normality test for the residuals; transformation is used if they are not normal.

c. Identify patterns of relationship between response and explanatory variables using correlation analysis and multicollinearity tests of the explanatory variables.

d. Identify spatial diversity and time by:

a. A combined and annual BreuschPagan test to observe spatial diversity.

b. The boxplot method to observe temporal diversity.

e. Perform GTWR modeling, which includes:

a. Calculating Euclid distance at coordinates $\left(u_{i^{\prime}} v_{i^{\prime}} t_{i}\right)$.

b. Obtaining optimum estimation of parameter $\tau$ iteratively with initial values $\tau_{0}$ and $b_{S T}=b_{S}$ or spatial bandwidth, by comparing the minimum cross-validation $(\mathrm{CV})$ value, thus obtaining parameter estimates $\mu$ and $\lambda$. c. Determining spatio-temporal bandwidth $\left(b_{S T}\right)$.

d. Calculating the weighting matrix of the GTWR model with kernel bisquare functions.

e. Estimating the GTWR parameters.

f. Interpret the results by drawing maps based on coefficients that have a significant effect on the construction sector GRDP in the GTWR model.

g. Draw conclusions and make suggestions.

\section{Results and Discussion}

\subsection{Description}

The relationship between the response and explanatory variables can be established based on Pearson correlation values, as shown in Table 2. Local revenue $\left(X_{2}\right)$ is the highest correlation coefficient value between the explanatory and response variables at 0.815 , while the lowest correlation is area $\left(X_{3}\right)$, at -0.181 . The correlation coefficient between local revenue and the GRDP of the construction sector is positive and high, as the infrastructure in many regions uses regional income and expenditure (APBD) budget funds, some of which are local revenue.

A multicollinearity test was conducted to determine the correlation between the explanatory variables used. It is performed by calculating the value of VIF (Variance Inflation Factor) with the formula $V I F_{k}=\frac{1}{1-R_{k}^{2}}$, with $\mathrm{k}$ being the many explanatory variables. is the coefficient of determination obtained from the explanatory variable chosen as the response variable, with the other explanatory variables becoming the explanatory variables for the response variable.

The results of the multicollinearity test are shown in Table 3. VIF values lower than 10 indicate that there is no multicollinearity in the explanatory variable used. The data used are panel data, so the VIF value is calculated for each year and a combination of all years. 
Table 2. Pearson correlation coefficient between explanatory and response variables

\begin{tabular}{cccccc}
\hline Response Variables & Population & Local Revenue & Area & Establishments & $\mathbf{n}$ \\
\hline GRDP of the construction sector & 0.424 & 0.815 & -0.181 & 0.675 & 833 \\
\hline
\end{tabular}

Table 3. Values the VIF of explanatory variables

\begin{tabular}{ccccc}
\hline \multirow{2}{*}{ Year } & \multicolumn{4}{c}{ Response variable } \\
\cline { 2 - 5 } & Population & Local Revenue & Area & Establishment \\
\hline Combination & 1.73 & 1.66 & 1.40 & 1.86 \\
2010 & 1.84 & 1.55 & 1.44 & 1.85 \\
2011 & 1.84 & 1.74 & 1.43 & 2.09 \\
2012 & 1.75 & 1.64 & 1.42 & 1.85 \\
2013 & 1.68 & 1.63 & 1.40 & 1.76 \\
2014 & 1.74 & 1.53 & 1.39 & 1.70 \\
2015 & 1.72 & 1.60 & 1.38 & 1.77 \\
2016 & 1.64 & 2.05 & 1.37 & 2.21 \\
\hline
\end{tabular}

Table 4. Breusch-Pagan Test Results

\begin{tabular}{ccc}
\hline Year & Breusch-Pagan Value & p-value \\
\hline Combination & 64.23 & $3.74 \times 10^{-13 *}$ \\
2010 & 13.09 & $0.011^{*}$ \\
2011 & 11.36 & $0.023^{*}$ \\
2012 & 10.54 & $0.032^{*}$ \\
2013 & 9.99 & $0.041^{*}$ \\
2014 & 11.27 & $0.024^{*}$ \\
2015 & 10.66 & $0.031^{*}$ \\
2016 & 9.35 & $0.053^{* *}$ \\
\hline
\end{tabular}

Note: * significant at a $5 \%$; ${ }^{* *}$ significant at a $10 \%$

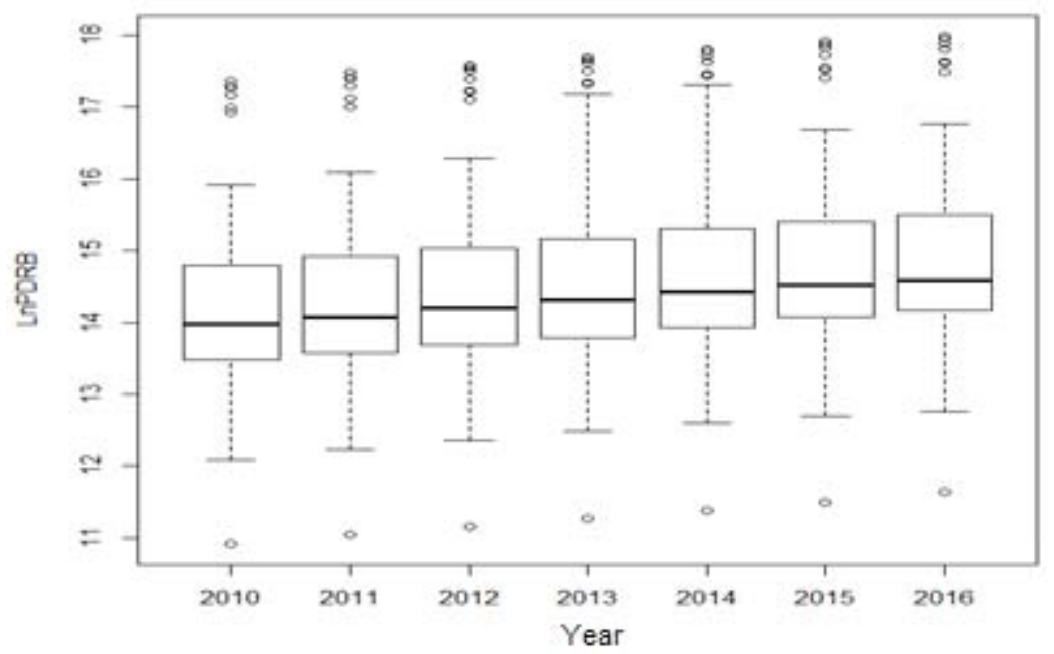

Figure 1. Temporal heterogeneity using a boxplot

Testing for the normality of the residuals obtained a value of 0.972 , with a p-value of of linear regression was conducted based on 0.000738 . This indicates that the distribution of the Shapiro-Wilk (SW) test. The test results the residuals from the model has not followed 
normal distribution. Transformation was made by the Box-Cox method to deal with side abnormalities. The Box-Cox transformation results obtained a minimum lambda value of -0.182 . The resulting lambda value is approaching 0 , so the transformation used in this study is the function of natural logarithms (ln) in the response variable.

Spatial heterogeneity testing using the Breusch-Pagan test statistic was performed to determine whether there was diversity due to spatial influence. The tests are conducted annually and simultaneously on the 119 regencies/municipalities in Java Island in 2010-2016. The Breusch-Pagan test results are presented in Table 4 . These, in combination and annually, are significant at the 5 percent level, apart from 2016, when it is significant at the $10 \%$ real level. It can therefore be said that there is spatial heterogeneity in the GRDP construction sector data of the regencies/ municipalities in Java Island in 2010-2016. Inequality of spatial diversity is thought to be caused by differences in characteristics in each location.

To ascertain the existence of temporal heterogeneity, the data were described using a boxplot, as shown in Figure 1. The figure shows that the distance between GRDP value quartiles in the construction sector is different each year. This difference illustrates the diversity of data, so it can be said that between years there is such diversity. LnGRDP in the construction sector in Java has spatial, as well as temporal diversity. One of the suitable models to model this in the construction sector in Java Island is the GTWR model.

\subsection{Geographically and Temporally Weighted Regression (GTWR) Model}

The weighting matrix used in the study was the Bisquare weighting function, which produces the same bandwidth in each location. Determination of optimum bandwidth was made by calculating the smallest CV (cross validation) value. This was 411.572 , with a spatiotemporal bandwidth value $\left(\mathrm{b}_{\mathrm{ST}}\right)$ of 5.518 . In addition, the optimum parameter ratio $(\tau)$ was generated at 0.512 , with a spatial distance parameter $(\lambda)$ of 0.922 , and temporal parameter $(\mu)$ of 0.472 .

\subsubsection{Estimator of the parameters of the GTWR model}

A description of the parameter estimator using the GTWR method is given in Table 5. The estimator of the parameter intercept in GTWR model, the LnPDRB of the construction sector in Java, ranged from 13.178 to 13.730 , or 528606.72 to 918043.45 million rupiahs if there were no changes in the explanatory variables. While the explanatory variables of population $\left(X_{1}\right)$, local revenue $\left(X_{2}\right)$ and the number of construction establishments $\left(\mathrm{X}_{4}\right)$ are positive, meaning that if there is an increase in population, local revenue or the number of construction establishments of 1 unit, the value of the GRDP of the construction sector will increase by $e^{\hat{\bar{B}}_{1}}, e^{\overline{\bar{\theta}}_{2}}$ or $e^{\hat{\bar{B}}_{4}}$ times if there is no change in the other explanatory variables. This is inversely proportional to the explanatory variable area $\left(X_{3}\right)$ which has a negative value in all regencies/municipalities every year, meaning that an area increase of $1 \mathrm{~km} 2$ will reduce the value of the construction sector GRDP by $e^{\hat{\theta}_{3}}$ and if there is no change in the other explanatory variables.

Table 5. Summary of the coefficient estimator of the parameters of the GTWR model

\begin{tabular}{ccccc}
\hline Variable & Minimum & Maximum & Mean & Standard Error \\
\hline Intercept & 13.178 & 13.730 & 13.450 & 0.158 \\
Population & $7.165 \times 10^{-7}$ & $1.164 \times 10^{-6}$ & $8.738 \times 10^{-7}$ & $1.398 \times 10^{-7}$ \\
Local Revenue & $4.488 \times 10^{-8}$ & $2.504 \times 10^{-7}$ & $5.858 \times 10^{-8}$ & $2.171 \times 10^{-8}$ \\
Area & $-3.048 \times 10^{-4}$ & $-1.202 \times 10^{-5}$ & $-2.074 \times 10^{-4}$ & $5.250 \times 10^{-5}$ \\
Establishment & $1.924 \times 10^{-4}$ & $7.961 \times 10^{-4}$ & $5.556 \times 10^{-4}$ & $1.799 \times 10^{-4}$ \\
\hline
\end{tabular}




\subsubsection{Interpretation of the GTWR model}

The GTWR model generates different parameter estimating values in each location and year. This is in accordance with the purpose of its use, which is to form a model in each region for every year (Conita \& Purwaningsih, 2017). The results of the model can be used to evaluate the policies that have been applied by each regency/municipality. In addition, it can also be used as a basis to decide whether the policies are still relevant or need to be updated. In the GTWR model, each variable has a different effect. Likewise, the magnitude of the parameter coefficient value also varies in each regency/municipality and year.

For example, the GTWR model for Malang Regency in 2015 is as follows:

$$
\hat{y}=e^{13.31+1.05 \times 10^{-6} x_{1}+8.96 \times 10^{-8} x_{2}-1.47 \times 10^{-4} x_{3}+3.40 \times 10^{-4} x_{4}}
$$

For Malang Regency in 2016 it is as follows:

$$
\hat{y}=e^{13.35+1.04 \times 10^{-6} x_{1}+6.04 \times 10^{-8} x_{2}-1.43 \times 10^{-4} x_{3}+3.67 \times 10^{-4} x_{4}}
$$

For Malang City in 2015 it is as follows:

$$
\hat{y}=e^{13.49+9.16 \times 10^{-7} x_{1}+5.40 \times 10^{-8} x_{2}-1.38 \times 10^{-4} x_{3}+3.58 \times 10^{-4} x_{4}}
$$

And for Malang City in 2016 it is as follows:

$$
\hat{y}=e^{13.58+8.32 \times 10^{-7} x_{1}+5.38 \times 10^{-8} x_{2}-1.35 \times 10^{-4} x_{3}+4.15 \times 10^{-4} x_{4}}
$$

The interpretation of the GTWR model for Malang Regency in 2015 is the estimated value of the construction sector GRDP of $e^{13.31}$ or 603197.53 million rupiahs if there is no change in the independent variables. If the population of Malang Regency in 2015 increases by 1 person, it will increase the estimated value of construction sector GRDP by $\mathrm{e}^{1.05 \times 10^{-6}}$, or 1.00000105 times, if other explanatory variables remain unchanged. The coefficient of the local revenue explanatory variable of $8.96 \times 10$ 8 explains that the estimated GRDP of the construction sector will increase by $\mathrm{e}^{8.96 \times 10^{-8}}$, or 1.0000000896 times, if local revenue increases by 1 million rupiahs and there is no change in the other explanatory variables. If there is a change of $1 \mathrm{~km} 2$ in the area of Malang Regency in 2015 and other explanatory variables do not change, then the estimated value of the GRDP of the construction sector will decrease by $\mathrm{e}^{-1.47 \times 10^{-4}}$, or 0.99985301 times. The estimation of the GRDP of the construction sector Malang Regency in 2015 will increase by $\mathrm{e}^{3.40 \times 10^{-4}}$ , or 1.00034006 times, when the number of construction establishments increases by 1 and other explanatory variables are unchanged.

\subsubsection{Testing the Parameters of the GTWR Model}

Testing of the GTWR model was conducted to establish the explanatory variables that influenced the response variable for each time and location. Most regions have different influential factors, which are because each regency/municipality has different characteristics, both in terms of geography, public facilities, social facilities and government. The differences in influencing factors allow each location to develop its own policies in accordance with the conditions and needs in their respective regions in order to increase the value of construction sector GRDP.

Regency/municipality grouping based on influential factors using the GTWR model is illustrated in Figure 2. In the GTWR model, two groups were formed. The first group was the regencies/municipalities whose construction sector GRDP was influenced by population $\left(X_{1}\right)$, local revenue $\left(X_{2}\right)$ and area $\left(X_{3}\right)$. The second group comprised regencies/ municipalities whose construction sector GRDP was influenced by population $\left(X_{1}\right)$, local revenue $\left(X_{2}\right)$, area $\left(X_{3}\right)$ and number of construction establishments $\left(X_{4}\right)$. 


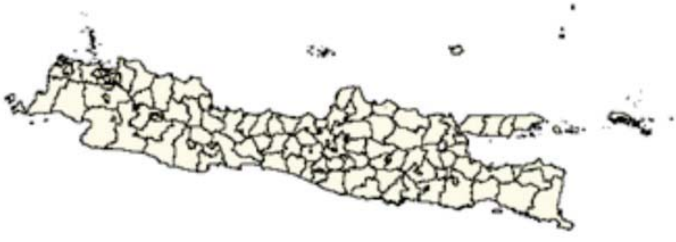

2010

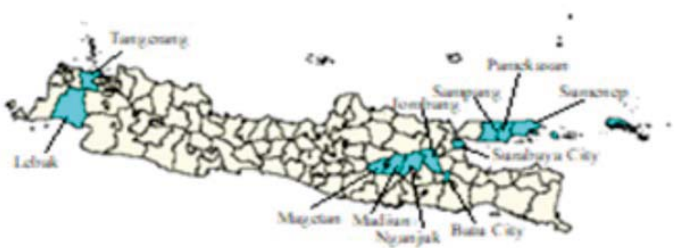

2012

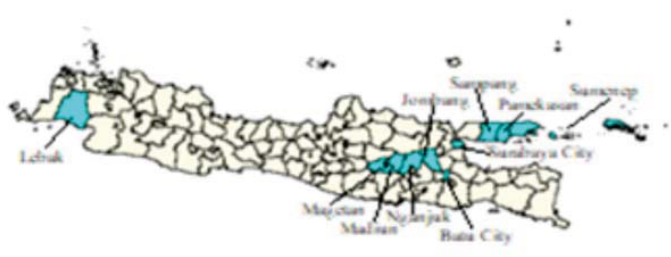

2014

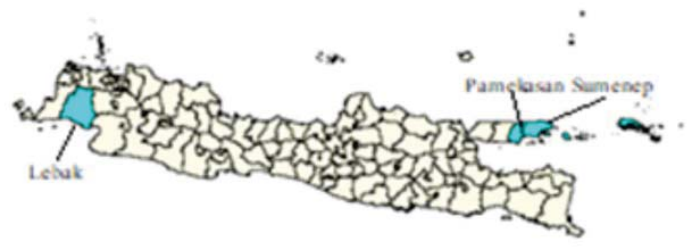

2011

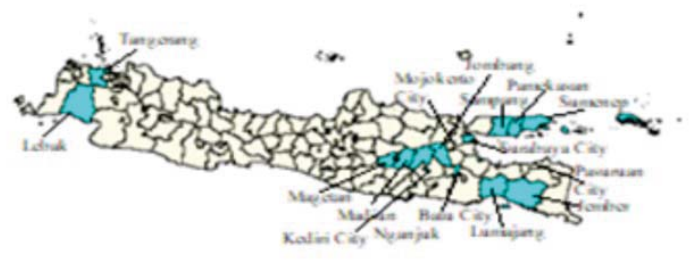

2013

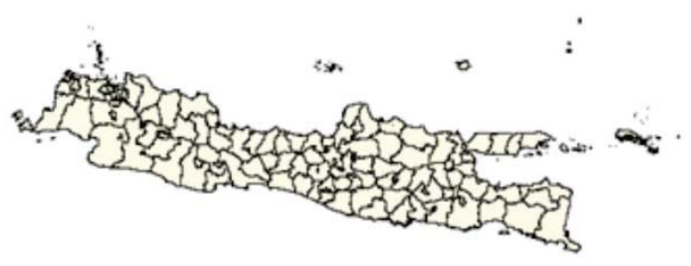

2015

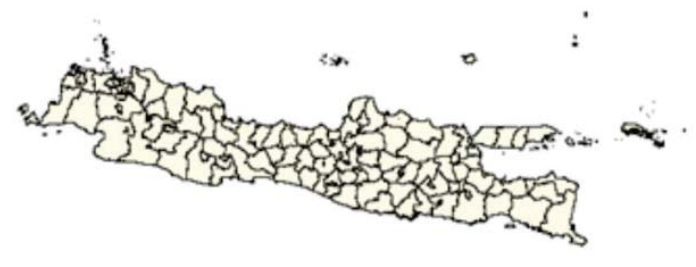

\section{Description:}

\section{$\mathrm{X}_{1}, \mathrm{X}_{2}, \mathrm{X}_{3}$}

$\mathrm{x}_{1} \mathrm{X}_{2}, \mathrm{X}_{3}, \mathrm{X}_{4}$

\section{6}

Figure 2. Map of regency/municipality distribution based on influencing factors

Table 6. Regency/municipality grouping based on influential factors

\begin{tabular}{|c|c|c|}
\hline Year & $X_{1}, X_{2}, X_{3}$ & $X_{1}, X_{2}, X_{3}, X_{4}$ \\
\hline 2010 & & All regencies/municipalities in Java \\
\hline 2011 & Pamekasan, Sumenep, Lebak & Other regencies/municipalities \\
\hline 2012 & $\begin{array}{l}\text { Jombang, Nganjuk, Madiun, Magetan, Sampang, Pame- } \\
\text { kasan, Sumenep, Surabaya City, Batu City, Lebak, Tan- } \\
\text { gerang }\end{array}$ & Other regencies/municipalities \\
\hline 2013 & $\begin{array}{l}\text { Lumajang, Jember, Jombang, Nganjuk, Madiun, Magetan, } \\
\text { Sampang, Pamekasan, Sumenep, Kediri City, Pasuruan } \\
\text { City, Mojokerto City, Surabaya City, Batu City, Lebak, } \\
\text { Tangerang }\end{array}$ & Other regencies/municipalities \\
\hline 2014 & $\begin{array}{l}\text { Jombang, Nganjuk, Madiun, Magetan, Sampang, Pame- } \\
\text { kasan, Sumenep, Surabaya City, Batu City, Lebak }\end{array}$ & Other regencies/municipalities \\
\hline 2015 & & All regencies/municipalities in Java \\
\hline 2016 & & All regencies/municipalities in Java \\
\hline
\end{tabular}


Details of the regency/municipality groupings based on influential factors are presented in Table 6 . The table shows that all regencies/municipalities in Java had the same influential factors in 2010, 2015 and 2016. Changes occurred in 2011-2014, when the explanatory variable of the number of construction establishments was not significant in several regencies/municipalities.

\section{Conclusion}

The factors that affected the GRDP of the construction sector varied amongst the regencies/municipalities in Java in the period 2010 to 2016; this can be used as material for policymaking and evaluation in accordance with the differing influential factors. The explanatory variable of population has a positive and significant effect. We know that humans need facilities that must be built to support their lives; increasing population in an area will require many such facilities.

The explanatory variable of local revenue also has a positive and significant effect. The construction of facilities built by local governments involves use of the Regional Revenue and Expenditure Budget, part of which is local revenue. So if a local government wants to increase the construction of facilities for the community, it is also necessary to increase local revenue as a source of development. The explanatory variable of area has a negative effect on each regency/ municipality and in each year. The smaller the area, the easier the access between regions, meaning development is faster and that there is an increase in the GRDP of the construction sector.

The explanatory variable of the number of construction establishments have a positive effect on each regency/municipality each year. However, in 2012-2014 some regencies/ municipalities did notseeasignificanteffect.The increasing number of construction companies is expected to significantly increase the GRDP of the construction sector, but in some regencies/ municipalities this has no significant effect ; for example, Sampang Regency, which has a large number of companies that made no significant contribution to increasing construction sector GRDP. The ease of obtaining permission to establish a company is unable to increase the GRDP of the construction sector.

\section{Acknowledgments}

We would like to acknowledge BPSStatistics Indonesia for data and funding support, both thesis mentors for their supporting knowledge, and all the team at the Statistics Department of IPB University.

\section{References}

Afandi, A. G., \& Soesatyo, Y. (2014). Pengaruh Industri Pengolahan, Perdagangan, hotel, dan Restoran, dan Pertanian terhadap PDRB Kabupaten Mojokerto (The Influence of the Processing Industry, Trade, Hotels and Restaurants, and Agriculture on the GRDP of Mojokerto Regency). Jurnal Pendidikan Ekonomi, 2(3), 1-16.

Anisah, Soedwiwahjon, \& Miladan, N. (2017). Analisis Bentuk Perkembangan Wilayah Kecamatan Kartasura Sebagai Kawasan Strategis Cepat Tumbuh (Analysis of form the regional development in Kartasura district as a rapidly growing strategic area). Region, 12(2), 111-118.

BPS-Statistics Indonesia. (2016). Produk Domestik Regional Bruto Kabupaten/Kota Jawa Timur menurut Lapangan Usaha 2011-2015 (Gross Regional Domestic Product of regency/ municipality of East Java by business sector 2011-2015). Surabaya: Statistics-East Java

BPS-Statistics Indonesia. (2017). Statistik Konstruksi 2016 (Construction Statistics 2016). Jakarta: BPS-Statistics Indonesia. 
Brunsdon, C., Fotheringham, A. S., \& Charlton, M. E. (1996). Geographically weighted regression: a method for exploring spatial nonstationarity. Geographical analysis, 28(4), 281-298.

Conita, Purwaningsih T. (2017). Under-five mortality rate modeling using geographically and temporal weighted regression (GTWR). Editor: -. Proceedings of 1st Ahmad Dahlan International Conference on Mathematics and Mathematics Education; 2017 October 13-14. Yogyakarta, Indonesia. Yogyakarta: Universitas Ahmad Dahlan.

Stewart Fotheringham, A., Charlton, M., \& Brunsdon, C. (1996). The geography of parameter space: an investigation of spatial non-stationarity. International Journal of Geographical Information Systems, 10(5), 605-627.

Fotheringham, A. S., Brunsdon, C., \& Charlton, M. (2003). Geographically weighted regression: the analysis of spatially varying relationships. John Wiley \& Sons.

Fotheringham, A. S., Crespo, R., \& Yao, J. (2015). Geographical and temporal weighted regression (GTWR). Geographical Analysis, 47(4), 431-452.

Giyarsih, S. R. (2010, July). Pola Spasial Transformasi Wilayah di Koridor Yogyakarta-Surakarta. In Forum Geografi (Vol. 24, No. 1, pp. 28-38).

Huang, B., Wu, B., \& Barry, M. (2010). Geographically and temporally weighted regression for modeling spatio-temporal variation in house prices. International Journal of Geographical Information Science, 24(3), 383-401.

Jayadinata, J. T. (1999). Tata Guna Tanah dalam Perencanaan Pedesaan. Perkotaan dan Wilayah, Edisi Ketiga, ITB, Bandung.

Naskah Akademik RUU Jasa Konstruksi. (2015). [internet]: http://www.dpr.go.id/doksileg/ proses1/RJ1-20150921-113904-7848.pdf [1 March 2018]

Nasution, H. S. (2017). Analisis Faktor-Faktor yang Mempengaruhi Pertumbuhan Produk Domestik Regional Bruto Era Desentralisasi Fiskal di Propinsi Banten Periode 2001: 1-2009: 4. Media Ekonomi, 18(2), 29-48.

Putra, N.B. (2015). Pengaruh Jumlah Penduduk dan Luas Wilayah terhadap PDRB di Kabupaten Bojonegoro 2010-2014 (Effect of Population and Area on GRDP in Bojonegoro District 20102014). [Skripsi]. Malang: Universitas Muhammadiyah Malang.

Safitri, I. \& Aliasuddin. (2016). Pengaruh Penduduk terhadap Pertumbuhan Ekonomi (Influence of Population on Economic Growth). Jurnal Ilmiah Mahasiswa (JIM), 1(1), 56-65.

Wibowo, S. N. E., Mamuaya, G. E., \& Djamaluddin, R. (2018, May). Land Subsidence Analysis of Reclaimed Land using Time-Lapse Microgravity Anomaly in Manado, Indonesia. In Forum Geografi (Vol. 32, No. 1, pp. 53-63). 